\title{
Katarzyna JARNO-CICHOSZ*
}

\author{
KOŚCIÓŁ PARAFIALNY PW. ŚWIĘTYCH APOSTOLÓW \\ PIOTRA I PAWLA W GRODZISKU W DEKANACIE UNIEJOWSKIM
}

\begin{abstract}
Zarys treści: Kościół parafialny pw. Świętych Apostołów Piotra i Pawła w Grodzisku to ciekawy przykład wzniesionego na początku XVII wieku z fundacji szlacheckiej obiektu sakralnego wyróżniającego się na tle krajobrazu architektonicznego regionu szczególnymi okolicznościami powstania. Obiekt wzniesiony został staraniem Jana Rudnickiego, kasztelana sieradzkiego, który zdecydował się na budowę świątyni pod koniec swojego życia, w podeszłym wieku, wiedząc, że oprócz pięciu córek nie doczeka się już żadnego potomka. Początkowo kościół posiadał skromniejszą formę - dzisiejszy wygląd zyskał w wyniku kilku kolejnych przebudów, które zostały przeprowadzone w XIX wieku. W XVII wieku świątynia ograniczała się jedynie do prostokątnej nawy, półkoliście zamkniętego prezbiterium oraz zakrystii. Stanowi ona przykład udanego połączenia form architektonicznych zakorzenionych w średniowieczu, nadal niezwykle popularnych na terenie dekanatu uniejowskiego, z elementami renesansowego wnętrza. Omawiany obiekt świadczy o pozycji i zamożności fundatora oraz jego trosce, by nawet po śmierci ostatniego Rudnickiego pamięć o tej rodzinie nie uległa zatarciu.
\end{abstract}

Słowa kluczowe: Grodzisko, kościół, parafia

Tytułowa świątynia to ciekawy przykład wzniesionego na początku XVII wieku obiektu sakralnego, wystawionego z fundacji szlacheckiej - staraniem Jana Rudnickiego, kasztelana sieradzkiego, który zdecydował się na budowę świątyni pod koniec swojego życia, ze świadomością, że umierając, nie pozostawi po sobie żadnego męskiego potomka' ${ }^{1}$ a jego dzieło będzie pełniło funkcję mauzoleum oraz pomnika - architektonicznej dominanty przypominającej o obecności w tym miejscu rodu Rudnickich. Sama lokalizacja kościoła pw. św. św. Piotra i Pawła podkreśla wspomniane funkcje, jako że został on usytuowany na wzniesieniu górującym nad wsią Grodzisko i okolicą. Ze względu na jego historię kościołowi temu, który nie doczekał się dotychczas opracowania, należy poświęcić więcej uwagi, i obok przebadania jego dziejów przywrócić mu $-\mathrm{w}$ formie próby rekonstrukcji - nowożytne formy (ryc. 1).

* Katarzyna Jarno-Cichosz, mgr historii i historii sztuki, doktorantka w Katedrze Historii Sztuki, Wydział Filozoficzno-Historyczny, Uniwersytet Łódzki, ul. Uniwersytecka 3, 90-137 Łódź.

${ }^{1}$ Podejmując decyzję o ufundowaniu kościoła pw. św. św. Piotra i Pawła w Grodzisku, Jan Rudnicki miał ok. 70 lat i był ojcem pięciu córek; Urzędnicy województwa łęczyckiego i sieradzkiego XVI-XVIII wieku. Spisy, red. A. Gąsiorowski, Kórnik 1993, s. 142; K. Niesiecki, Korona Polska, t. 3, Lwów 1740, s. 902-903 


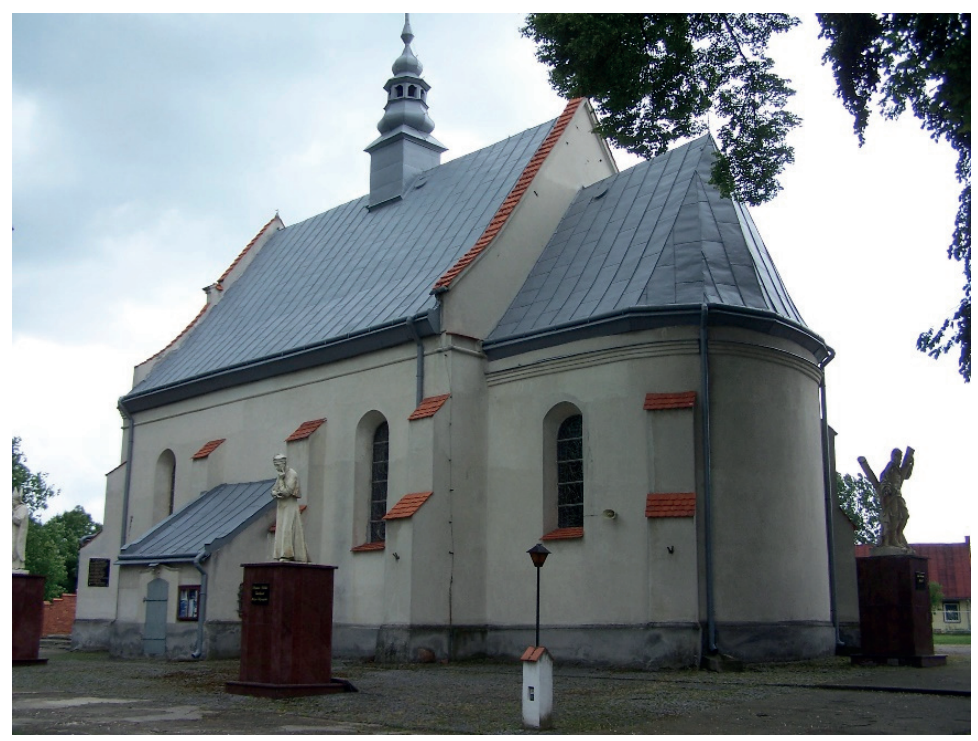

Ryc. 1. Kościół parafialny pw. św. św. Piotra i Pawła, Grodzisko (fot. K. Jarno-Cichosz, 2014)

Parafia Grodzisko została erygowana na przełomie XIV i XV wieku². W tym czasie wzniesiono także pierwszy, drewniany kościół pw. Nawrócenia św. Pawła, którego fundatorem był Jan Chebda z Niewiedza Niewieski, ówczesny właściciel Grodziska ${ }^{3}$. Świątynia murowana została wybudowana dopiero w 1612 roku z fundacji Jana Rudnickiego herbu Lis, chorążego mniejszego sieradzkiego, a następnie kasztelana sieradzkiego ${ }^{4}$, o czym przypominają dwie inskrypcje znajdujące się w świątyni: pierwsza, pochodząca z tego samego okresu co świątynia, została umieszczona w portalu głównym; druga, z początku XX wieku, umieszczona jest nad drzwiami do zakrystii ${ }^{5}$. Pierwsza z inskrypcji - dziś słabo czytelna - ma charakter dewocyjny i zlokalizowana została w partii belkowania architektonicznego portalu pierwotnie pełniącego funkcję głównego wejścia do świątyni, mieszczącego się obecnie w kruchcie zachodniej. Druga z inskrypcji została umieszczona wtórnie w portalu prowadzącym z nawy kościoła do zakrystii

${ }^{2}$ Stownik geograficzny Królestwa Polskiego i innych krajów słowiańskich, red. F. Sulimierski, B. Chlebowski, W. Walewski, Warszawa 1881, t. 2, s. 842; P. Maluśkiewicz, Województwo konińskie, Warszawa 1983, s. 154-163.

${ }^{3}$ Archiwum Diecezji Włocławskiej (dalej: ADW), Akta Arcybiskupów Gnieźnieńskich (dalej AAG), Wizytacja (dalej: Wiz.) 72, k. 951.

${ }^{4}$ Urzędnicy województwa tęczyckiego i sieradzkiego XVI-XVIII wieku. Spisy, red. A. Gąsiorowski, Kórnik $1993 \ldots$... s. 142.

${ }^{5}$ ECELESIA ANNO 1612 A JOANNE RUDNICKI, HAEREDE/DE ZBYLCZYCE AEDIFICATA: ANNO 1620 A SIMONE RUD-/NICKI EPISCOPO WARMIENSI CONSECRATA. ANNO/ 1909 SUMPTU PAROCHIANORUM ET CURA SIGIS-/MUNDI WRONOWSKI, RECTORIS ECCESIAE HUIUS/ RESTAURATA AC DEPICTA. 
podczas renowacji w 1909 roku i może sugerować istnienie w tym miejscu wcześniejszej inskrypcji.

Prace przy budowie kościoła w Grodzisku zostały zakończone najprawdopodobniej do 1618 roku $^{6}$, lecz jego wyposażanie zajęło kilka kolejnych lat. Prace te przebiegały pod czujnym okiem fundatora - zmarł on 23 maja 1620 roku $^{7}$, przekazując wieś Grodzisko na uposażenie kościoła ${ }^{8}$. Zgodnie ze swoim życzeniem Jan Rudnicki został pochowany we wnętrzu świątyni - można przypuszczać, że w krypcie znajdującej się pod prezbiterium ${ }^{9}$. Jeszcze w tym samym roku nastąpiła konsekracja kościoła, której dokonał brat Jana - Szymon Rudnicki, biskup warmiński. Dokładna data konsekracji nie jest znana, jednak zachowało się wiele przekazów informujących, że rocznicę tejże uroczystości obchodzono w pierwszą niedzielę po wspomnieniu św. Marcina (11 listopada $)^{10}$.

Kościół pw. św. św. Piotra i Pawła jest świątynią orientowaną z jednonawowym, trójprzęsłowym, oszkarpowanym z zewnątrz korpusem, do którego przylega od wschodu węższe, półkoliście zamknięte prezbiterium (ryc. 2). Od północy w jego wschodniej części zlokalizowana jest zakrystia, od południa w części centralnej niewielka kruchta, od zachodu zaś druga, większa kruchta, w której usytuowano wejścia do świątyni. Korpus, prezbiterium oraz kruchta zachodnia przykryte zostały dachem dwuspadowym, a zakrystia i kruchta południowa dachami pulpitowymi. Nad częścią centralną korpusu umieszczono sygnaturkę.

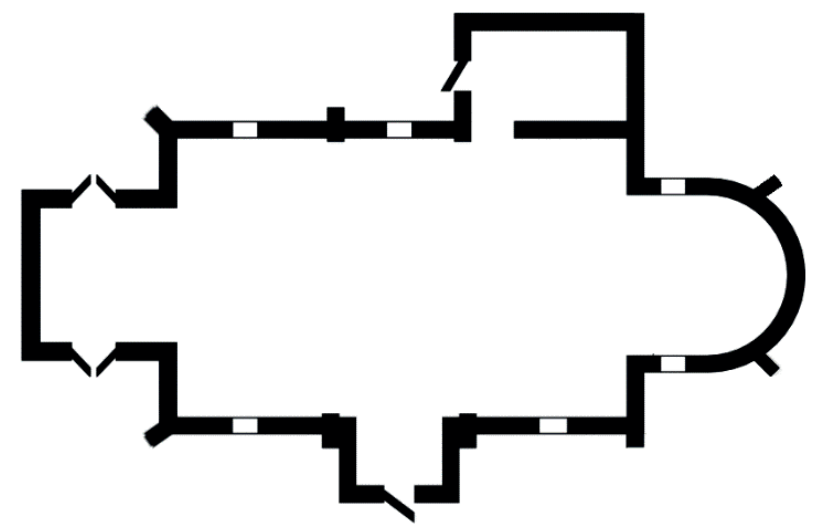

Ryc. 2. Plan kościoła parafialnego pw. św. św. Piotra i Pawła, Grodzisko Źródło: opracowanie własne

${ }^{6}$ ADW, AAG, Wiz. 72, k. 953.

${ }^{7}$ Urzędnicy województwa łęczyckiego i sieradzkiego XVI-XVIII wieku. Spisy, red. A. Gąsiorowski, Kórnik 1993..., s. 142; S. Librowski, Repertorium akt wizytacji kanonicznych dawnej archidiecezji gnieźnieńskiej, Akta, Biblioteki i Muzea Kościelne, t. 37, 1978, s. 154-163.

${ }^{8}$ ADW, AAG, Wiz. 88.

${ }^{9}$ ADW, AAG, Wiz. 137, k. 96.

${ }^{10}$ ADW, AAG, Wiz. 72, k. 951, Wiz. 88, Wiz. 137, k. 94; Akta par. Grodzisko 6. 
Artykulację pionową elewacji zewnętrznych stanowią jedynie dwuuskokowe szkarpy rozmieszczone naprzemiennie z wysokimi, zamkniętymi półkoliście oknami, podziały poziome natomiast tworzą niewysoki, gładki cokół nieznacznie wysunięty przed lico ściany oraz skromny gzyms biegnący poniżej linii dachu. Elewację zachodnią zdobił pierwotnie portal o formie architektonicznej: otwór drzwiowy zamknięty spłaszczonym łukiem flankowany przez dwie półkolumny wspierające belkowanie $\mathrm{z}$ inskrypcją. W polach zawartych pomiędzy tukiem a oprawą architektoniczną portalu umieszczono dwie główki putt. Trudno dziś określić, jak wyglądało pierwotne, siedemnastowieczne zwieńczenie portalu, gdyż podczas dobudowy kruchty został on częściowo przesłonięty nową bryłą.

We wnętrzu świątyni, w partii korpusu, płaszczyzny ścian zostały podzielone parami pilastrów umieszczonych analogicznie do usytuowanych na zewnątrz szkarp. Wieńczą je kompozytowe kapitele, na których wsparto zwielokrotniony gzyms obiegający całą nawę, ozdobiony ponad kapitelami pilastrów skromnymi kartuszami herbowymi: Paparona i Rola (na ścianie północnej), Lis i Grzymała (na ścianie południowej). Pomiędzy pilastrami umieszczono $\mathrm{w}$ ścianach płytkie wnęki, którym nadano formy łuków arkad. Korpus i prezbiterium przykryte zostały sklepieniami zwierciadlanymi; w zakrystii zdecydowano się na sklepienie kolebkowe. W części zachodniej korpusu znajduje się chór muzyczny o konstrukcji drewnianej wraz z organami pochodzącymi z lat 20. XX wieku ${ }^{11}$ (ryc. 3).

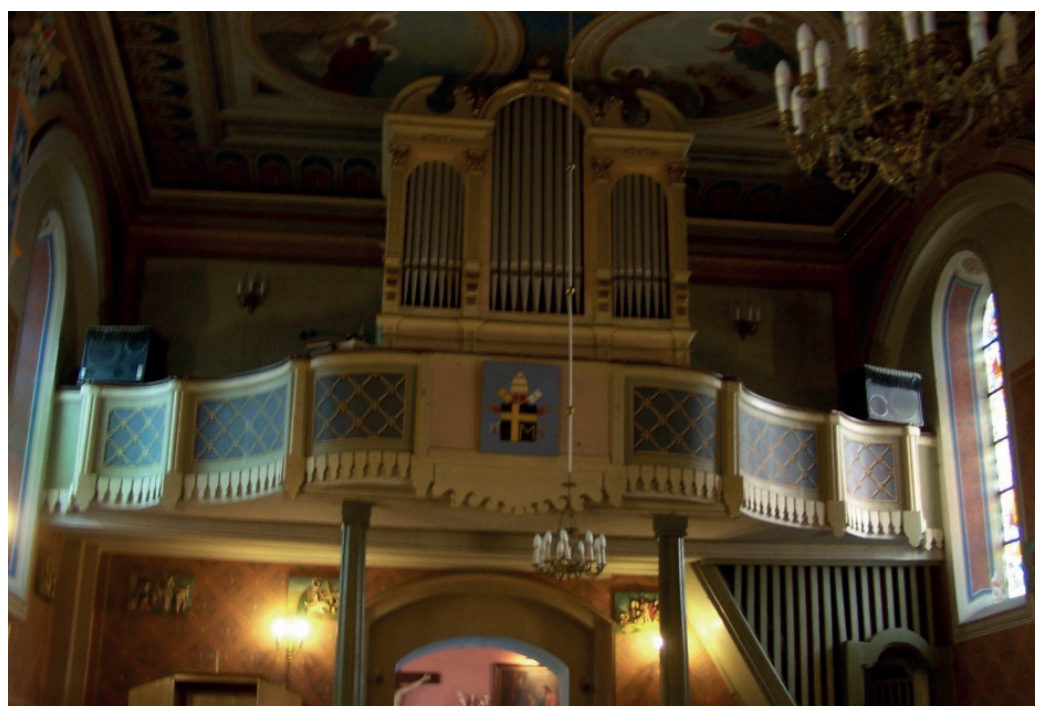

Ryc. 3. Chór, kościół parafialny pw. św. św. Piotra i Pawła, Grodzisko (fot. K. Jarno-Cichosz, 2014)

${ }^{11}$ ADW, Akta par. Grodzisko 4. 
Obiekt ten stanowi przykład udanego połączenia form architektonicznych zakorzenionych w średniowieczu, nadal niezwykle popularnych na terenie dekanatu uniejowskiego przy fundacjach sakralnych o porównywalnej skali, z elementami renesansowego wnętrza. Partiami nawiązującymi do wcześniejszej tradycji architektonicznej są niewątpliwie szkarpy oraz wysokie, wąskie okna. Także plan kościoła, a w szczególności prezbiterium, wykazuje podobieństwo do średniowiecznych w charakterze świątyń wznoszonych na początku XVII wieku (wskazać tu można m.in. plany kościołów w Chruślinie i Witoni ${ }^{12}$ ). Wnętrze świątyni w Grodzisku stanowi tymczasem niezwykle udany przykład adaptacji wzorców renesansowych w artykulacji ścian oraz formach sklepień.

Zaznaczyć przy tym trzeba, że współczesne formy tytułowego obiektu są wynikiem kilku renowacji oraz kilkukrotnej rozbudowy i trudno dziś jednoznacznie odtworzyć jego pierwotny wygląd. Partiami siedemnastowiecznymi kościoła są korpus, prezbiterium oraz zakrystia wzniesione i najprawdopodobniej otynkowane przed 1636 rokiem, na co wskazują informacje zawarte w przeprowadzonej w tymże roku wizytacji ${ }^{13}$ (ryc. 4,5 ).

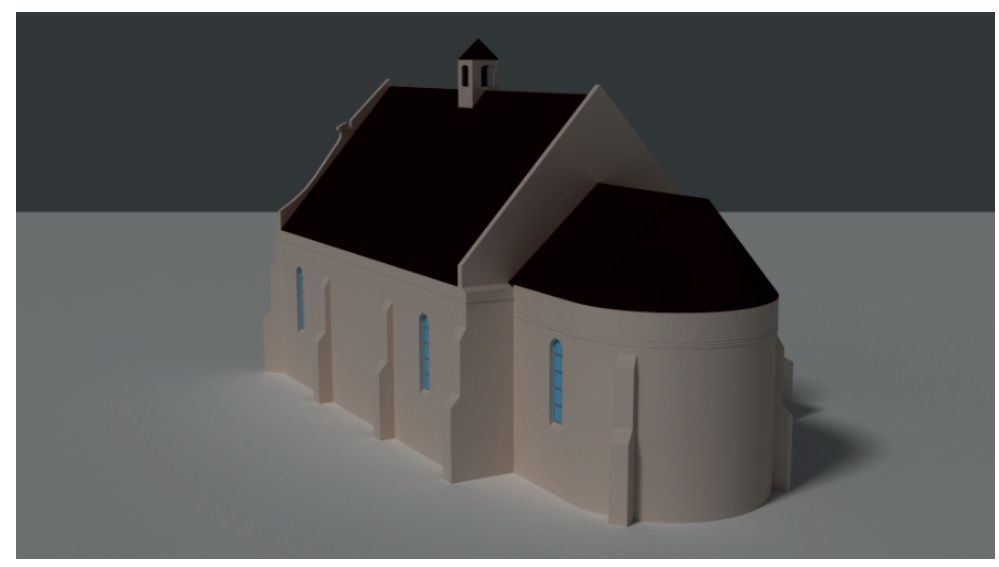

Ryc. 4. Rekonstrukcja siedemnastowiecznego wyglądu kościoła parafialnego pw. św. św. Piotra i Pawła, Grodzisko

Źródło: opracowanie własne

W kolejnych latach stan kościoła ulegał powolnemu pogorszeniu. Gontowy dach wymagał reperacji już na początku XVIII wieku, lecz nie przeprowadzano wówczas przy nim prac remontowych ${ }^{14}$. Pod koniec stulecia podczas jednej $\mathrm{z}$ wizytacji stan kościoła opisywany jest już jako zły ${ }^{15}$. Autor wizytacji zwraca

${ }^{12}$ Vide: P. Gryglewski, Vetusta monumenta. Szlacheckie mauzoleum od pol. XV w. do XVII w., Łódź 2002; tenże, De Sacra Antiquitate. Odwołania do przeszłości w polskiej architekturze sakralnej XVI wieku, Warszawa 2012.

${ }^{13}$ ADW, AAG, Wiz. 5, k. 21.

${ }^{14}$ ADW, AAG, Wiz. 9, k. 45.

${ }^{15}$ ADW, AAG, Wiz. 72, k. 954. 
uwagę na ubytki w podłodze drewnianej wykonanej z tarcic, a także stary dach, miejscami popsuty. Ponadto wspomina zatartą malaturę ścian, potwierdzając tym samym, że kościół w Grodzisku był już wówczas otynkowany i pomalowany ${ }^{16}$. Dekadę później, podczas kolejnej wizytacji, odnotowano pogarszający się stan kościoła, jednocześnie zaznaczając, że rozpoczęto prace remontowe. Objęto nimi stary dach, „teraz poprawiany” ${ }^{17}$, lecz wizytator zwraca także uwagę na bardzo zły stan drewnianego chóru oraz części sufitu ${ }^{18}$. Wymienione prace miały najpewniej charakter zachowawczy i służyły doraźnemu zabezpieczeniu świątyni, o czym świadczy opis kościoła w parafii Grodzisko zamieszczony w wizytacji dziekańskiej z 1812 roku. Uwagę zwraca w nim, obok ponownej informacji o nie najlepszym stanie obiektu, informacja, że świątynia ta nie posiada żadnych kaplic ${ }^{19}$.

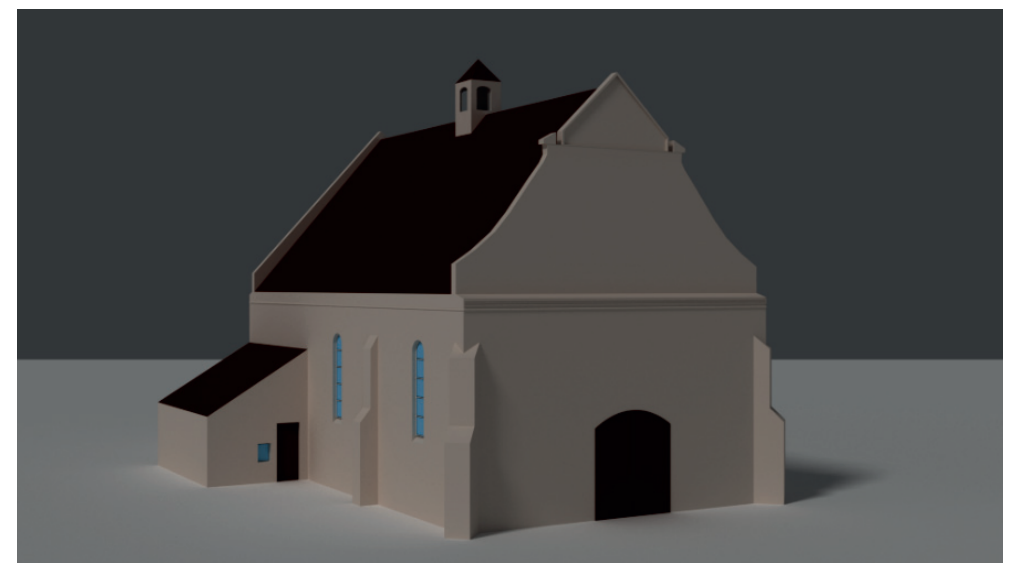

Ryc. 5. Rekonstrukcja siedemnastowiecznego wyglądu kościoła parafialnego pw. św. św. Piotra i Pawła, Grodzisko

Źródło: opracowanie własne

Dopiero pod koniec lat 20. XIX wieku rozpoczęto systematyczne prace mające przywrócić kościołowi w Grodzisku dawną świetność. Pierwsze zabiegi przeprowadzono we wnętrzu, ,(ołtarz) wielki roboty staroświecki porządny, w roku 1829 kosztem dziedzica (...) W. J. Długołędzkiego odmalowany, lakierowany miejscami wyzłocony"20. W kolejnych latach prace renowacyjne objęły „dach gontem niedawno pokryty”21, który mimo to „potrzebuje reperacyi” ${ }^{22}$. Dopiero z początku lat 30. XIX wieku pochodzi pierwsza wzmianka o istnieniu przy

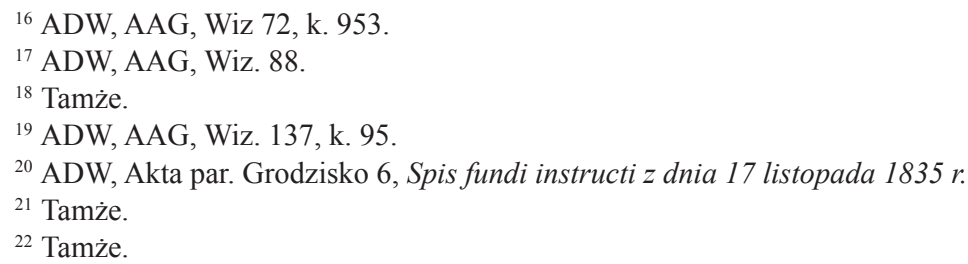


kościele kruchty zachodniej: „od strony zachodniej jest kruchta w pruski mur wystawiona $\mathrm{z}$ sufitem i podłogą z desek na fugi, ma dwa poboczne małe okienka oszklone bez krat, także dwoje drzwi podwornych pobocznych z żelaznymi zawiasami na drągi zamykanych"23. W tym czasie przy kościele znajdowała się także drewniana dzwonnica w złym stanie.

W drugiej połowie XIX wieku świątynia w Grodzisku zaczęła przyjmować znane do dzisiaj formy. Ze względu na częste problemy z utrzymaniem w dobrym stanie gontu podjęto decyzję o pokryciu dachu kościoła blachą: „Kościół ten pokryty jest blachą żelazną w r: 1863 staraniem ks. Józefa Nawackiego, który na ten dach wydatkował własnych pieniędzy rb: sto sześćdziesiąt, a resztę ze składki parafialnej, który to dach kosztował rb: pięćset pięćdziesiąt dwa kopiejek osiem i pół" ${ }^{24}$. Na początku lat 70. XIX wieku w wyglądzie kościoła zachodziły kolejne zmiany spowodowane złymi warunkami pogodowymi i wcześniejszymi zaniedbaniami: wymieniona została sygnaturka, a także przebudowano kruchtę zachodnią, o czym informuje dziekan podczas wizytacji na początku 1876 roku, tak opisując zastane zmiany:

„Po zawaleniu sygnatury na kościele tutejszym przez burze i wiatry jako starej wzniósł (...) ks. Józef Nawacki nową wieżę z nowego zupełnie materiału w r. 1870 - wieża ta pokryta blachą białą angielską kosztowała rb: trzysta osiem kopiejek pięćdziesiąt trzy i pół.

Po obaleniu się także w pruski mur dawno zbudowanej kruchty, zbudował tenże ks. Józef Nawacki nową murowaną kruchtę, blachą krytą - w r: 1871 co kosztowało rb: dwieście czterdzieści pięć kopiejek trzydzieści dwie - nie licząc $w$ to cegły dwanaście tysięcy sztuk darowanej przez W.J. Wyganowskiego Dziedzica Zbylczyc.

Pokrycie dachu nad zakrystią blachą żelazną w r: 1874 staraniem ks. Józefa Nawackiego - kosztuje rb: sto siedem kopiejek pięćdziesią.." ${ }^{25}$.

Stan ten potwierdza kolejna wizytacja z 1889 roku, uzupełniająca obraz przeobrażeń kościoła w Grodzisku o informacje o pracach przeprowadzonych w 1879 roku: „W 1879 kosztem W.W. Wyganowskiego kolatora (...) kościół zewnątrz i wewnątrz wyrestaurowany, odświeżony i wewnątrz ściany wokoło na wysokości 2 1/2 łokcia olejną, a całe wnętrze klejową farbą pomalowane" ${ }^{\prime 26}$.

Aby dopełnić obrazu zmian, jakie zaszły w architekturze kościoła w Grodzisku pod koniec XIX wieku, a których efektem jest dzisiejszy wygląd świątyni, należy wspomnieć opis zamieszczony w spisie inwentarza z 1891 roku, który notuje istnienie drugiej kruchty: „Na kościele jest sygnatura w wieżyczce pokrytej blachą angielską - po lewej stronie zakrystia murowana, a po prawej kruchta nowo pomiędzy dwoma (szkarpami) pobudowana $\mathrm{z}$ drzwiami blachą obitymi.

\footnotetext{
${ }^{23}$ ADW, Akta par. Grodzisko 6, Spis inwentarza z $1835 r$.

${ }^{24}$ ADW, Akta par. Grodzisko 6, Wizyta dziekańska z dn. 21 lutego/4 marca $1876 r$.

${ }^{25}$ Tamże.

${ }^{26}$ ADW, Akta par. Grodzisko 6, Wizyta dziekańska z dn. 13/25 listopada 1889 r.
} 
$\mathrm{Z}$ frontu kościoła jest także wielka kruchta również murowana pobudowana $\mathrm{w}$ r. 1871. Dach na kościele, kruchtach i zakrystyi jest z blachy żelaznej potrzebuje pomalowania i w niektórych miejscach reperecyi" ${ }^{27}$.

Dzięki trosce administratorów parafii Grodzisko tamtejsza świątynia, choć często wymagająca napraw i modernizacji, przetrwała minione wieki w dobrym stanie (ryc. 6), co stanowi pokłosie intensywnych prac przeprowadzanych w drugiej połowie XIX wieku, pomimo iż kolejne wizytacje odnotowywały konieczność wykonania większych prac remontowych o różnej skali. W tym czasie - zapewne wychodząc naprzeciw potrzebom wiernych - zwiększono dotychczasową kubaturę kościoła poprzez dobudowę kruchty zachodniej, w której dziś umieszczone są ławki dla wiernych.

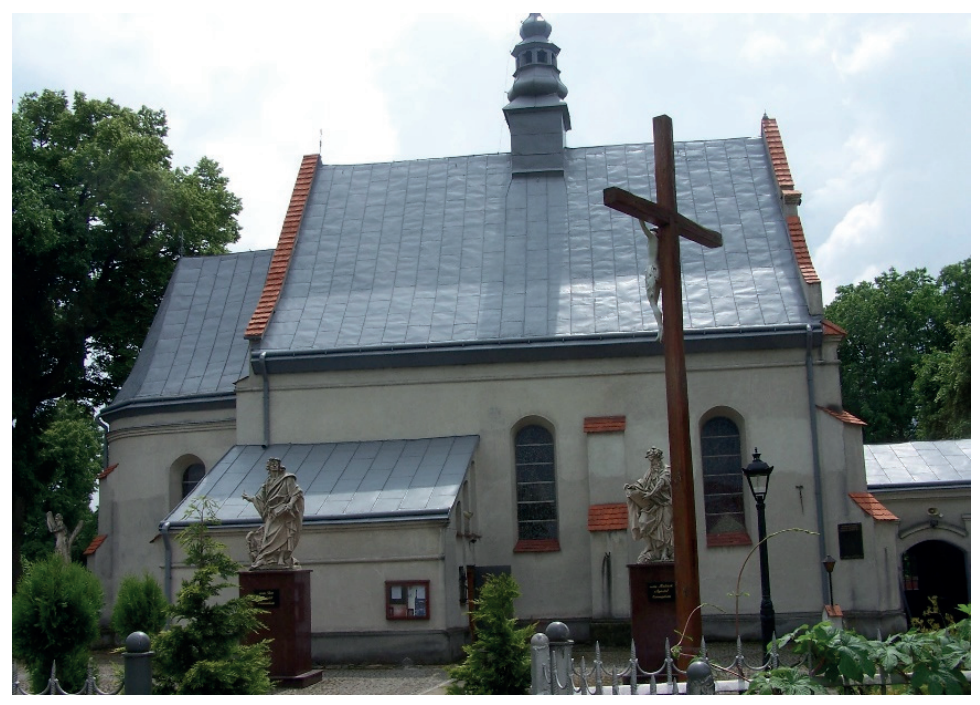

Ryc. 6. Obecny wygląd kościoła parafialnego pw. św. św. Piotra i Pawła w Grodzisku (fot. K. Jarno-Cichosz 2014)

$\mathrm{Z}$ przytoczonych informacji, ale także $\mathrm{w}$ świetle zachowanego materiału źródłowego niemożliwe jest odtworzenie pierwotnych dekoracji malarskich tytułowego obiektu. Bogate polichromie zdobiące obecnie świątynię są, wraz z oknami witrażowymi, efektem prac renowacyjnych przeprowadzanych pod koniec minionego stulecia. Pierwotnie okna świątyni były jedynie oszklone, a na przestrzeni wieków sufity, a w szczególności sklepienie nawy, opisywane były jako drewniane, wykonane $\mathrm{z}$ desek $^{28}$.

Osobnym problemem pozostaje wyposażenie kościoła św. św. Piotra i Pawła, które na przestrzeni lat uległo daleko idącym przekształceniom. Wśród najistotniejszych jego elementów należy wymienić trzy ołtarze wzmiankowane już

${ }^{27}$ ADW, Akta par. Grodzisko 6, Spis inwentarza z dn. 12/24 kwietnia $1891 \mathrm{r}$.

${ }^{28}$ ADW, Akta par. Grodzisko 6. 
w XVII wieku - główny z obrazami św. św. Apostołów Piotra i Pawła (zasuwa) oraz Najświętszej Marii Panny, a także dwa ołtarze boczne: św. św. Aniołów Stróżów oraz św. Tekli, wspominane do końca XVIII wieku ${ }^{29}$. Z biegiem lat stan poszczególnych ołtarzy uległ pogorszeniu, tak że na początku XIX wieku odnotowano $\mathrm{w}$ świątyni obecność tylko jednego ołtarza ${ }^{30}$. Dopiero z czasem, podczas wspomnianych już prac z lat 20 . XIX wieku, do wnętrza kościoła powróciły trzy ołtarze - główny (z obrazem Matki Boskiej z początku XIX wieku) oraz dwa ołtarze boczne poświęcone Jezusowi Chrystusowi (obecnie z obrazem Serca Jezusowego) oraz św. Tekli (obecnie z obrazem św. św. Piotra i Pawła) ${ }^{31}$.

Oprócz ołtarzy uwagę zwraca także ambona w formie łodzi usytuowana przy ścianie północnej korpusu w sąsiedztwie wejścia do zakrystii oraz przyścienna chrzcielnica ze sceną Chrztu Chrystusa z dekoracją snycerską, zlokalizowana przy południowym ołtarzu bocznym. Na uwagę zasługują także dwa przechowywane w kościele portrety: Jana i Szymona Rudnickich pochodzących z pierwszej połowy XVII wieku, przemalowane w wieku XVIII.

W świetle zachowanych materiałów oraz w oparciu o analizę form architektonicznych i stanu zachowania należy uznać, że obiekt ten posiada ogromną wartość dla kultury lokalnej. Stanowi on widoczny znak minionej historii, jest świadectwem życia i wiary wybitnego człowieka - Jana Rudnickiego, który u kresu swojego życia podjął się fundacji kościoła-mauzoleum upamiętniającego jego osobę oraz jego brata, biskupa Szymona - ostatnich męskich przedstawicieli rodu. Rudnicki zdecydował się na wzniesienie kościoła murowanego, o formach zewnętrznych zgodnych z panującymi na tym obszarze na początku XVII wieku trendami, jednak wnętrzu świątyni nadał formy renesansowe. Mimo licznych przeciwności losu obiekt ten przetrwał w bardzo dobrym stanie, choć na przestrzeni wieków jego formy uległy znacznej modyfikacji.

\section{Bibliografia}

\section{Źródla}

Archiwum Diecezji Włocławskiej:

Archiwum Arcybiskupów Gnieźnieńskich, Wizytacja 5, Wizytacja 8, Wizytacja 9, Wizytacja 13, Wizytacja 48, Wizytacja 72, Wizytacja 88, Wizytacja 137.

Akta par. Grodzisko 4.

Akta par. Grodzisko 5.

Akta par. Grodzisko 6.

\section{Literatura}

Gryglewski P., De Sacra Antiquitate. Odwołania do przeszłości w polskiej architekturze sakralnej XVI wieku, Warszawa 2012.

Gryglewski P., Vetusta monumenta. Szlacheckie mauzoleum od pot. XV w. do XVII w., Łódź 2002. Katalog Zabytków Sztuki w Polsce, red. J. Z. Łoziński, t. 5, z. 26, Warszawa 1957.

${ }^{29}$ ADW, AAG, Wiz 5, k. 21; Wiz. 8, k. 13; Wiz. 9, k. 45--46; Wiz. 13, k. 9--10; Wiz. 72, k. 956--957, Wiz. 88.

${ }^{30}$ ADW, AAG, Wiz 137, k. 96.

${ }^{31}$ ADW, Akta par. Grodzisko 6. 
Librowski S., Repertorium akt wizytacji kanonicznych dawnej archidiecezji gnieźnieńskiej, Akta, Biblioteki i Muzea Kościelne, t. 37, 1978.

Maluśkiewicz P., Województwo konińskie, Warszawa 1983.

Niesiecki K., Korona Polska, t. 3, Lwów 1740.

Słownik geograficzny Królestwa Polskiego i innych krajów słowiańskich, red. F. Sulimierski, B. Chlebowski, W. Walewski, Warszawa 1881, t. 2.

Urzędnicy województwa tęczyckiego i sieradzkiego XVI-XVIII wieku. Spisy, red. A. Gąsiorowski, Kórnik 1993.

[Wpłynęło: maj 2016; akceptacja: czerwiec 2016]

\title{
THE PARISH CHURCH OF SAINT APOSTLES PETER AND PAUL IN GRODZISK IN THE UNIEJÓW DEANERY
}

\begin{abstract}
Summary
Saint Apostles Peter and Paul's Church in Grodzisk is an interesting example of a church founded by a nobleman. It was erected at the beginning of the $17^{\text {th }}$ century by the castellan of Sieradz, Jan Rudnicki, who had five daughters and no male heir. He decided to build a temple when he reached an old age and knew that he would not have any more children.

Originally, the church had a much more modest form than today. Its present appearance is the result of several reconstructions carried out in the $19^{\text {th }}$ century. Initially it only had a rectangular nave, a semicircular closed chancel and a sacristy. It is an example of a successful combination of architectural forms rooted in the Middle Ages, still very popular in the Uniejów deanery, with Renaissance elements inside. The church is a testimony to the position and wealth of its founder and his concern to commemorate the family and ensure that it will be remembered long after the death of the last Rudnicki.
\end{abstract}

Keywords: Grodzisko, church, parish 